\title{
The ability of the green peach aphid (Myzus persicae) to penetrate mesh crop covers used to protect potato crops against tomato potato psyllid (Bactericera cockerelli)
}

\author{
Howard London $^{1,2}$, David J Saville ${ }^{1,3}$, Charles N Merfield ${ }^{\text {Corresp., } 4}$, Oluwashola Olaniyan ${ }^{1}$, Stephen D Wratten ${ }^{1}$ \\ 1 Bio-Protection Research Centre, Lincoln University, Lincoln, New Zealand \\ 2 National Agricultural Research and Extension Institute, Mon Repos, East Coast Demerara, Guyana \\ 3 Saville Statistical Consulting Limited, Lincoln, Canterbury, New Zealand \\ 4 The BHU Future Farming Centre, Lincoln University, Lincoln, New Zealand \\ Corresponding Author: Charles N Merfield \\ Email address: charles.merfield@bhu.org.nz
}

In Central and North America, Australia and New Zealand, potato (Solanum tuberosum) crops are attacked by Bactericera cockerelli, the tomato potato psyllid (TPP). 'Mesh crop covers' which are used in Europe and Israel to protect crops from insect pests, have been used experimentally in New Zealand for TPP control. While the covers have been effective for TPP management, the green peach aphid (GPA, Myzus persicae), has been found in large numbers under the mesh crop covers. This study investigated the ability of the GPA to penetrate different mesh hole sizes. Experiments using four sizes $(0.15 \times 0.15$, $0.15 \times 0.35,0.3 \times 0.3$ and $0.6 \times 0.6 \mathrm{~mm}$ ) were carried out under laboratory conditions to investigate: (i) which mesh hole size provided the most effective barrier to GPA; (ii) which morph of adult aphids (apterous or alate) and/or its progeny could breach the mesh crop cover; (iii) would leaves touching the underside of the cover, as opposed to having a gap between leaf and the mesh, increase the number of aphids breaching the mesh; and (iv) could adults feed on leaves touching the cover by putting only their heads and/or stylets through it?

No adult aphids, either alate or apterous, penetrated the mesh crop cover; only nymphs did this, the majority being the progeny of alate adults. Nymphs of the smaller alatae aphids penetrated the three coarsest mesh sizes; nymphs of the larger apterae penetrated the two coarsest sizes, but no nymphs penetrated the smallest mesh size. There was no statistical difference in the number of aphids breaching the mesh crop cover when the leaflets touched its underside compared to when there was a gap between leaf and mesh crop cover. Adults did not feed through the mesh crop cover, though they may have been able to sense the potato leaflet using visual and/or olfactory cues and produce nymphs as a result. As these covers are highly effective for managing TPP on field potatoes, modifications of this protocol are required to make it effective against aphids as well as TPP. 


\section{The ability of the green peach aphid (Myzus persicae) to penetrate}

\section{2 mesh crop covers used to protect potato crops against tomato potato}

\section{3 psyllid (Bactericera cockerelli).}

4 Howard London ${ }^{1,4}$, David J. Saville ${ }^{1,3}$, Charles Merfield ${ }^{2}$, Oluwashola Olaniyan ${ }^{1}$, Stephen D.

5 Wratten $^{1 *}$

$6 \quad{ }^{1}$ Bio-Protection Research Centre, P.O. Box 85084, Lincoln University, Lincoln 7647, New

7 Zealand

82 The BHU Future Farming Centre, P.O. Box 69113, Lincoln 7640, New Zealand

$9{ }^{3}$ Saville Statistical Consulting Limited, P.O. Box 69192, Lincoln 7640, New Zealand

$10{ }^{4}$ National Agricultural Research and Extension Institute, Agriculture Road, Mon Repos, East

11 Coast Demerara, Guyana

*Corresponding author: Dr Charles N. Merfield, The BHU Future Farming Centre, P.O. Box 69113, Lincoln 7646, New Zealand. Tele +64 3325 3684, Email charles.merfield@bhu.org.nz

\section{Abstract}

17 In Central and North America, Australia and New Zealand, potato (Solanum tuberosum) crops are attacked by Bactericera cockerelli, the tomato potato psyllid (TPP). 'Mesh crop covers' which are used in Europe and Israel to protect crops from insect pests, have been used experimentally in New Zealand for TPP control. While the covers have been effective for TPP management, the

21 green peach aphid (GPA, Myzus persicae), has been found in large numbers under the mesh crop 
22 covers. This study investigated the ability of the GPA to penetrate different mesh hole sizes.

23 Experiments using four sizes $(0.15 \times 0.15,0.15 \times 0.35,0.3 \times 0.3$ and $0.6 \times 0.6 \mathrm{~mm})$ were carried out

24 under laboratory conditions to investigate: (i) which mesh hole size provided the most effective

25 barrier to GPA; (ii) which morph of adult aphids (apterous or alate) and/or its progeny could

26 breach the mesh crop cover; (iii) would leaves touching the underside of the cover, as opposed to

27 having a gap between leaf and the mesh, increase the number of aphids breaching the mesh; and

28 (iv) could adults feed on leaves touching the cover by putting only their heads and/or stylets

29 through it?

30 No adult aphids, either alate or apterous, penetrated the mesh crop cover; only nymphs did this,

31 the majority being the progeny of alate adults. Nymphs of the smaller alatae aphids penetrated

32 the three coarsest mesh sizes; nymphs of the larger apterae penetrated the two coarsest sizes, but

33 no nymphs penetrated the smallest mesh size. There was no statistical difference in the number

34 of aphids breaching the mesh crop cover when the leaflets touched its underside compared to

35 when there was a gap between leaf and mesh crop cover. Adults did not feed through the mesh

36 crop cover, though they may have been able to sense the potato leaflet using visual and/or

37 olfactory cues and produce nymphs as a result. As these covers are highly effective for managing

38 TPP on field potatoes, modifications of this protocol are required to make it effective against

39 aphids as well as TPP.

40 Keywords: aphids, tomato potato psyllid, mesh crop covers, insect nets, insect exclusion screens. 


\section{Introduction}

43 Potato (Solanum tuberosum L.) is a globally important food crop, having the fourth highest

44 production level of 388 million tonnes in 2017 after maize (Zea mays L.), wheat (Triticum

45 aestivum L.), and rice (Oryza sativa L.) (FAOSTAT 2020). In New Zealand, potatoes are the

46 highest grossing vegetable, with consumers purchasing approximately NZ \$119 million in 2013

47 (Vegetables.co.nz 2020). However, potato production is threatened by the tomato potato psyllid

48 (TPP, Bactericera cockerelli (Ŝulc 1908) (Hemiptera, Triozidae)). This phloem-feeding insect

49 originated in North and central America and was first identified in New Zealand in 2006 (Teulon

50 et al. 2009) and in Western Australia in 2017 (International Plant Protection Convention 2017).

51 TPP feeds on plants in the Solanaceae and Convolvulaceae families (Wallis 1955), and can cause

52 complete crop loss (Munyaneza 2013; Munyaneza 2014).

53 Due to the negative impacts of TPP on potatoes in New Zealand, organic farmers asked

54 researchers to investigate non-chemical management approaches. Biological options such as the

55 predatory mite Anystis baccarum L. (Geary et al. 2016) were explored, but without commercial

56 success. In the laboratory, the coccinellid beetle Cleobora mellyi (Mulsant 1850) has very high

57 consumption rates of TPP, but this remains to be confirmed in glasshouse and field crops

58 (O’Connell et al. 2012; Pugh et al. 2015).

59 'Mesh crop covers' (also referred to as 'insect nets', 'Agronets', 'insect exclusion screens') have

60 been used in Europe for many years to protect a wide range of crops, but not potatoes, from both

61 invertebrate and vertebrate pests (Collier 2001; Collier 2002; Hill 1987; Saidi et al. 2013). In

62 New Zealand, however, such covers have only recently been investigated experimentally. Mesh

63 crop covers with a hole size up to $0.6 \mathrm{~mm}$ were completely impermeable to TPP in laboratory

64 tests, and were able to reduce TPP populations in field trials to very low levels, even 
65 outperforming insecticides (Merfield 2017; Merfield et al. 2015a; Merfield et al. 2015b; Merfield 66 et al. 2019).

67 Despite the promising results obtained with mesh crop covers for control of TPP, an unexpected

68 result was that aphids, believed to be mostly the green peach aphid (GPA, Myzus persicae

69 (Sulzer, 1776) (Hemiptera: Aphididae)) appeared in large numbers under the mesh crop covers,

70 particularly in the 2016-17 field trials where their populations were significantly higher than

71 uncovered controls, even though the edges of the mesh crop covers were dug into the soil,

72 creating a complete seal (Merfield 2017; Merfield et al. 2019).

73 Aphids can significantly affect plant growth and development, reducing yields. In addition, GPA

74 in particular, is a vector of many plant viruses that also cause significant yield losses (Capinera

75 2001).

76 The GPA is the most common and widespread aphid on potatoes in New Zealand, as it feeds on

77 many host-plant species (Stufkens \& Teulon 2001). It is also the most economically important

78 aphid on potatoes, both in New Zealand and worldwide, because it transmits both potato virus Y

79 and leaflet curl virus, which are among the most damaging of the potato viruses (Marczewski

80 2001; Saguez et al. 2013; Srinivasan et al. 2013; Woodford 1992). The main management tool

81 for aphids in potatoes is insecticides. However, the GPA has developed resistance to a number of

82 these (Bass et al. 2014; Foster et al. 2007), which means that both novel and improved non-

83 chemical control techniques are required.

84 With mesh crop covers being highly effective for TPP management on potatoes, the major

85 challenge is understanding how aphids are circumventing mesh crop covers. Also it is unclear if

86 adults can, from outside the mesh crop cover, feed on potato leaves touching the underside of it.

87 If so, this means aphids outside the mesh crop cover could transmit viruses to potatoes under it. 
88 This could discourage seed-potato growers from using the mesh crop cover as a management

89 option for TPP because of virus transmission to tubers intended for propagation.

90 With these gaps in knowledge, the present research was therefore designed to investigate (i) if

91 aphid stylets can penetrate mesh crop cover of different hole sizes; (ii) if there is a difference in

92 this respect between alate and apterous adults and/or if their progeny have the ability to penetrate

93 mesh crop cover as individuals; (iii) if having potato leaves touching the mesh crop cover from

94 below increases the number of individual aphids penetrating it, compared to when the leaves do

95 not touch the mesh crop cover; and (iv) if adult aphids are capable of feeding on potato leaves

96 through the mesh crop cover.

\section{Materials and methods}

98 GPA was sourced from a colony cultured on Brassica rapa subsp. chinensis (L.) pak choi

99 (cultivar: Mei Qing Choi F1) kept at Lincoln University in a controlled-temperature room. The

100 room was kept at $16 \mathrm{~h}$ day length, temperature of $23^{\circ} \mathrm{C}$ with a $4{ }^{\circ} \mathrm{C}$ range and $60 \%$ relative

101 humidity. Potato plants (cv. Ilam Hardy) were grown in a glasshouse at the Lincoln University

102 plant nursery to provide leaflets for the laboratory experiment.

103 For the laboratory work, two, nine-cm diameter Petri dishes were used to create two

104 compartments separated by mesh crop cover; the top dish contained the aphids and the bottom

105 one a single potato leaflet. In the 'control' treatments, three aphids were placed in the bottom

106 dish (Fig. 1). A piece of moist tissue paper was placed in the bottom dish to maintain humidity.

107 Leaflets were then collected from potato plants and cotton wool was wrapped around the petiole

108 of the leaflet, which was inserted into an Eppendorf tube filled with water to maintain leaflet

109 turgidity. The tube with leaflet inserted was placed in the lower dish with the adaxial surface 
110 facing up. The mesh crop cover was carefully glued around the full circumference of the opening

111 between the two dishes, because, in previous experiments by Hodge et al. (2019), aphids could

112 locate and penetrate minimal gaps between the mesh crop cover and hard surfaces. The two Petri

113 dishes were then held together with plastic food wrap. For the mesh crop cover treatments, three

114 adult aphids were inserted through a hole (15 $\mathrm{mm}$ diameter) in the top of the upper dish, after

115 which the hole was sealed with mesh crop cover $(0.15 \times 0.15 \mathrm{~mm}$ mesh $)$ held in place by adhesive 116 tape.

117 There was a total of 24 treatments in a $4 \times 2 \times 3$ factorial design: four mesh crop cover hole sizes $\times$ 118 two aphid morphs (apterous or alate) $\times($ three leaflet/aphid positions), in a randomised complete 119 block, with five replicates. Eight of these treatments were controls, one for each of the 4 mesh 120 crop cover hole sizes and 2 aphid morphs, in which three aphids were placed directly on the 121 leaflet under the mesh crop cover. The other $16(=4 \times 2 \times 2)$ treatments had a mesh crop cover 122 barrier between aphids and leaflets. The mesh crop cover hole sizes stated by the manufacturer 123 were $0.15 \times 0.15 \mathrm{~mm}, 0.15 \times 0.35 \mathrm{~mm}, 0.3 \times 0.3 \mathrm{~mm}$ and $0.6 \times 0.6 \mathrm{~mm}$. Aphid morphs were apterous 124 or alate, while leaflet positions were touching or not touching the mesh crop cover barrier. The 125 experiment ran for $72 \mathrm{~h}$, at which point the number of aphids, both adults and nymphs, on the 126 leaflets were counted. The experiment was conducted in a controlled temperature room as above.

127 To investigate whether adult aphids could feed through the mesh crop cover, all adults in the 128 upper dish $(n=240=16 \times 5 \times 3)$, were lightly touched with an artist's fine brush (size 00$)$ at 12,24 , 12936 and 48 hours through the opening of the top Petri dish. Therefore, 240 individuals were 130 touched four times each, giving a total of 960 tests of feeding. Those that moved following 131 probing were considered to not have been feeding, while those that remained in the same 
132 position following probing were judged as having their stylets inserted into the leaflet and

133 therefore, to be feeding (Auclair 1963; Giordanengo et al. 2010).

134 Mesh crop covers with hole sizes $0.15 \times 0.15 \mathrm{~mm}$ and $0.15 \times 0.35 \mathrm{~mm}$ were supplied by AB

135 Ludvig Svensson (www.ludvigsvensson.com) as ECONET 1515 and ECONET 1535. Those

136 measuring $0.3 \times 0.3 \mathrm{~mm}$ and $0.6 \times 0.6 \mathrm{~mm}$ were supplied by Crop Solutions Ltd.

137 (www.cropsolutions.co.uk) and were custom-made for an earlier field trial (Merfield 2017). To

138 test the accuracy of the measurement for each mesh crop cover hole size used in this experiment,

139 ten random samples of each type were selected and 10 holes of each sample were measured

140 under a Nikon SMZ25 microscope (magnification range $0.63-15.75 \times$ ). The mean, minimum and

141 maximum mesh hole size measurements are presented in Table 1.

142 All data were analysed in a randomised block analysis of variance (ANOVA) (with a factorial

143 treatment structure) using GenStat ${ }^{\circledR} 18^{\text {th }}$ edition. The response variable (number of aphids on

144 potato leaflets) was subjected to a square-root transformation to normalise the data before

145 analysis. Also, the analysis was split into two ANOVAs to achieve homogeneity of variance. (1)

146 The eight controls ( 4 mesh hole-sizes $\times 2$ aphid-morphs), which were relatively highly variable,

147 were analysed separately as a $4 \times 2$ factorial with 5 blocks. (2) For the 16 non-control treatments,

148 six were all zeroes and hence had zero variability, so were omitted from the analysis, leaving 10

149 treatments which were analysed as a $(2 \times 2+1) \times 2$ factorial with 5 blocks.

\section{Results}

151 For the eight control treatments, with aphids below the mesh, there were no significant

152 differences in nymph numbers produced by the two aphid morphs, no significant linear or 
153 quadratic components of mesh crop cover hole size (assuming these were in the ratio $1: 2: 3$ :

154 6), nor any significant interaction components (Table 2).

155 In the 16 treatments with adults placed above the mesh cover, only nymphal, not adult aphids

156 were able to pass through the mesh. Nymphs of the smaller alate adults penetrated the $0.15 \times 0.35$,

$1570.3 \times 0.3$ and $0.6 \times 0.6$ meshes but not the $0.15 \times 0.15$ mesh (Table 2). Nymphs of the larger

158 apterous adults penetrated the $0.3 \times 0.3$ and $0.6 \times 0.6$ meshes but did not breach the $0.15 \times 0.15$ and

$1590.15 \times 0.35$ ones.

160 Comparing when leaflets touched or did not touch the mesh crop cover, there was no significant

161 difference in the number of nymphs penetrating the mesh $(\mathrm{P}=0.612)$. The interaction between

162 aphid morph (alate and apterous) and the leaflet touching mesh crop cover or not was also not

163 significant $(\mathrm{P}=0.066)$.

164 No aphids, at any time fed through the mesh crop cover, as all moved when probed with the 165 artist's brush.

\section{Discussion}

\section{Mesh crop cover hole size and aphid penetration}

168 The fact that no adult aphids penetrated the covers, differs from the result of Hodge et al. (2019)

169 studying GPA and the melon aphid (Aphis gossypii (Glover 1877)). They found that adult GPA

170 did penetrate LS ECONET 1515, but no GPA adults penetrated the larger hole LS ECONET

171 1535, a result which appears inconsistent. Hodge et al. (2019) did, however, find that nymphs

172 penetrated the mesh, in agreement with these results.

173 That adults did not penetrate mesh, but newly hatched nymphs did, suggesting a means by which

174 aphids entered all mesh covered plots in the field trial of Merfield (2017): adult aphids that 
175 alighted on the upper surface of the mesh, produced nymphs, which are small enough to

176 penetrate the mesh, and once through that they can reproduce on the potato crop. This result

177 needs to be verified under field conditions.

178 The extent to which of aphids penetrate mesh and for mesh to control aphids is clearly variable.

179 For example, Bethke et al. (1994) who worked with adult aphids, found GPA could not pass

180 through a square, brass mesh with hole sizes ranging from $0.19 \mathrm{~mm}^{2}$ to $0.94 \mathrm{~mm}^{2}$, but melon

181 aphid could penetrate meshes larger than $0.46 \mathrm{~mm}^{2}$. Using mosquito nets of knitted polyester,

$18230 \mathrm{gm}^{-2}$ and a mesh size of 25 holes per $\mathrm{cm}^{2}$, untreated or treated with deltamethrin, supported

$18350 \mathrm{~cm}$ above seedling cabbages (Brassica oleracea L.), Martin et al. (2006) found the treated

184 nets had significantly lower numbers of plants infested with the mustard aphid (Lipaphis erysimi

185 (Kaltenbach 1843)). In subsequent work, Martin et al. (2013) used mesh with $0.9 \mathrm{~mm}$ diameter,

186 treated with alphacypermethrin and two untreated nets, one with the same hole size and the other

187 with a smaller one of $0.4 \mathrm{~mm}$, and control without mesh, to cover pot-grown cabbages in the

188 field with the mesh supported $30 \mathrm{~cm}$ above the plants. They found no cabbage aphid

189 (Brevicoryne brassicae L.) under the $0.9 \mathrm{~mm}$ alphacypermethrin treated and untreated $0.4 \mathrm{~mm}$

190 mesh, but a small, yet statistically significant greater number, under the untreated $0.9 \mathrm{~mm}$ mesh.

191 In comparison, both GPA and mustard aphids (counted together as 'green aphids'), were not

192 present under the treated $0.9 \mathrm{~mm}$ mesh but were present in much larger numbers than cabbage

193 aphid in the two other meshes. The untreated $0.9 \mathrm{~mm}$ mesh had a statistically significant

194 population 5.8 times larger than the non-covered control while the $0.4 \mathrm{~mm}$ mesh had more than

195 twice the number of aphids than the control, although the difference was not statistically

196 significant. Licciardi et al. (2007), using deltamethrin-treated polyester mesh with 40 holes $/ \mathrm{cm}^{2}$, 197 kept $50 \mathrm{~cm}$ above cabbages, with the mesh either removed during the day ('temporary') or kept 
198 permanently on the crop, found that aphids infested the untreated control immediately on

199 planting out the crop. The temporary mesh was infested at 20 days after planting (DAP), and the

200 permanent mesh at $30 \mathrm{DAP}$, but then, the aphid numbers under the permanent screen rapidly

201 increased to finish at approximately four times that under the temporary mesh. In orchard trials

202 in France and Italy using mesh covers with hole sizes of either $2.2 \times 5.4 \mathrm{~mm}$ or $3 \times 7.4 \mathrm{~mm}$ to

203 control codling moth (Cydia pomonella L.), Alaphilippe et al. (2016) found that rosy apple aphid

204 (RAA, Dysaphis plantaginea (Passerini 1860)) and woolly apple aphid (Eriosoma lanigerum

205 (Hausmann, 1802)) populations increased. In contrast, Dib et al. (2010) found mesh covers

206 reduced RAA populations and also those of their ant mutualists as well as their predators under

207 covers also used for codling moth control. In a comparison of nets treated and untreated with

208 insecticides against black bean aphids (Aphis fabae (Scopoli 1763)) on French bean (Phaseolus

209 vulgaris L.), Gogo et al. (2014) found both mesh types significantly reduced aphid populations

210 compared with the control, but did not eliminate them.

211 In a few cases, mesh crop covers appeared to be impenetrable to aphids, or at least can prevent

212 aphids reaching crops, though this varies with aphid species e.g., cabbage aphid cv. GPA (Martin

213 et al. 2013), and could be related to size, though other factors, e.g., behavioural, may also have a

214 role. However, in most cases discussed above, mesh covers appeared only to delay aphids

215 reaching the crops, and, in some cases, aphid populations then rapidly built to levels much higher

216 than those in untreated controls or insecticide treatments. It is hypothesised that the mesh is

217 preventing, or at least reducing the range and number of aphid natural enemies that can reach the 218 crop.

219 Aphids are also not the only insect species that can circumvent mesh. Talekar et al. (2003) and

220 Piccard et al. (2007) reported that adult female moths of the armyworm (Spodoptera littoralis 
221 (Boisduval 1833)) laid eggs on the top of a hooped screen, and the newly hatched larvae were

222 sufficiently small to penetrate the mesh and drop onto the crop below. Merfield (2017) found a

223 large number of lacewings (Micromus tasmaniae (Walker 1860)) in plots of potatoes under

224 mesh, following aphid outbreaks under the mesh. Lacewing adults are much too large to

225 penetrate mesh, and the mesh was dug into the soil preventing entry from the edges, so it was

226 hypothesised that the lacewings laid eggs on the mesh, and then the neonate larvae penetrated the

227 mesh. As aphids, lacewings and armyworms would not be expected to lay eggs or produce

228 nymphs in the absence of suitable hosts, this indicates that the insects can detect their hosts

229 through the mesh, even when the mesh is at some distance from the crop (Licciardi et al. 2007;

230 Talekar et al. 2003).

231 Difference between the progeny of alate and apterous adults to penetrate mesh crop cover

232 In the present study, nymphs produced by alate adults penetrated the $0.15 \times 0.35$ mesh crop cover,

233 while those produced by apterous adults did not. This supports the findings of (Dixon \& Wratten

234 1971) who found that alate aphids were smaller, and produced fewer and smaller nymphs than

235 did apterous aphids, which indicates that only the smallest size mesh crop cover hole size

$236(0.15 \times 0.15 \mathrm{~mm})$ would be an effective barrier. For mesh crop cover with larger hole sizes,

237 neonate nymphs of both adult morphs can enter the mesh crop cover, so both alate and apterous

238 adults are potential threats to the crop. However, apterous aphids, lacking wings, could arrive

239 only on the outside of mesh crop cover from other plants bordering the mesh crop cover. In the

240 field trial of Merfield (2017) and Merfield et al. (2019), the periphery of mesh crop cover was

241 kept free of vegetation with residual herbicides and tillage such that apterous aphids walking

242 onto the mesh crop cover should have been eliminated, yet all mesh crop cover plots were 
243 infested by aphids. It is therefore believed, that nymphs, which infested the mesh crop cover

244 treatments in those trials, were produced by alate adults.

\section{Adult aphid feeding through mesh and implications for virus transmission}

246 That adults were not found to feed through the mesh indicates potato viruses will not be

247 transmitted through mesh. However, this result is not direct evidence for lack of transmission, as

248 it only demonstrated a lack of feeding but not a lack of probing. GPA can also transmit viruses

249 by probing (Radcliffe \& Ragsdale 2002). Direct testing of virus transmission is required, using

250 virus-infected aphids to test the rates of transmission when mesh is present or not.

\section{Solutions for aphids penetrating mesh crop covers.}

252 That some aphid species, and also armyworm (Licciardi et al. 2007; Talekar et al. 2003) can

253 circumvent mesh indicates that for some insect pests, additional control measures will be

254 required when using covers. Three general approaches are suggested: (i) modify the physical

255 properties of the mesh to prevent pests alighting or reproducing on it; (ii) use insecticide or

256 repellent-treated mesh covers to kill or repel alighting pests; (iii) use supplemental biological

257 control. For aphids on potatoes, the approach used should ideally also ensure that virus

258 transmission is minimised.

259 A range of research has altered the physical properties of mesh crop covers to both repel and 260 attract insects. Some of this research can be considered for field potatoes. These alterations

261 include: different colours (Ben-Yakir et al. 2012a), and ultra-violet light properties (Ben-Yakir et 262 al. 2012b), such that the mesh prevents aphids alighting.

263 Insecticide treated mesh crop covers have been discussed above, and, are clearly highly effective 264 in some situations. A further refinement of this approach has been to create attractive areas on 265 the mesh, e.g., yellow spots, with only the attractive areas treated with insecticides (Ben-Yakir et 
266 al. 2014). Chemical repellants can also be used in place of biocides (Martin et al. 2013).

267 However, the insecticides and repellents are lost from the mesh covers over time, so the efficacy 268 of treated mesh covers reduces, meaning their effective lifespan can be less than that of untreated 269 mesh covers (Dáder et al. 2015). Treating mesh also increases cost, and may require personnel to 270 use protective equipment when handling and storing the mesh covers. If a single chemical is used 271 to treat the mesh, this is likely to create increased pressure for evolved resistance, both against 272 biocides, and, also repellents (Foster et al. 2007). This could be partially mitigated through 273 impregnating the mesh covers with multiple insecticides with different modes of action, but, at 274 further increased cost.

275 A range of biological control approaches could be used. In the case of armyworm (discussed 276 above), infestations were effectively controlled using the biological control agent (BCA) Bacillus 277 thuringiensis (Talekar et al. 2003). In field crops, microbial BCAs could be applied through the 278 mesh (Ester et al. 1994; Merfield 2018). Augmentative biological control using predators and 279 parasitoids is widely used in protected cropping, such as glasshouses. Mesh crop covers are 280 considered to be a form of protected cropping, in that they should prevent introduced BCAs 281 escaping from the crop, so existing glasshouse biocontrol solutions could be leveraged. For 282 example, Gagnon Lupien et al.(2014) suggested the release of the commercially available 283 coccinellid Adalia bipunctata (L.) to compensate for the lack of aphid natural enemies under 284 mesh crop covers. Other biological control agents (BCAs) that have been used to successfully 285 manage GPA in protected envrionments include, Aphidius matricariae, Aphidius colemani 286 (Zamani et al. 2007) and Micromus tasmaniae (Harcourt 1996; Jonsson et al. 2009).

287 Augmentative biological control with insects could be further enhanced by the use of banker 288 plants (which provide supplemental food for beneficial insects, which helps them maintain a 
289 stable population) (Frank 2010) grown under the mesh / among the potato crop; this approach is

290 already used for control of GPA (Andorno \& López 2014).

\section{Conclusions}

292 Because of commercial availability and cost, it is recommended that the $0.6 \times 0.6 \mathrm{~mm}$ mesh crop 293 cover be used to manage TPP on potatoes, even though this mesh can be penetrated by GPA

294 nymphs. Further research is required to confirm GPA nymphs' ability to penetrate mesh covers in 295 the field and whether or not mesh is an effective barrier to virus spread, both by adults and 296 nymphs. A considerable amount of research is required into methods to control GPA and other 297 aphid species in mesh-covered potato crops. If mesh crop cover is combined with additional 298 approaches that achieve a high level of GPA control and therefore that of potato viruses, the 299 benefits to the potato seed industry are likely to be considerable. Mesh crop covers have been in 300 use across Israel and Europe since the early 1990s and the area used in Europe is estimated at 30150,000 ha, with hundreds of ha on individual farms (Ian Campbell, Crop Solutions Ltd., personal 302 communication). Mesh crop covers are therefore a completely farm-proven, large-scale, 303 technology. If an effective means of managing aphids on potatoes under mesh crop covers can be 304 developed, it has the potential to be a viable option for management of TPP on potato in New 305 Zealand and globally.

\section{Acknowledgements}

307 The authors thank Brent Richards and Leona Meachen from Lincoln University plant nursery for 308 assisting in growing potato plants; Jenny Brookes for the supply of GPA; Brian Kwan for 309 technical advice; Janine Johnson for editorial assistance; Crop Solutions Ltd and AB Ludvig 310 Svensson for donating mesh crop cover samples. 


\section{Funders}

312 Ministry of Foreign Affairs and Trade, New Zealand, and the Bio-Protection Research Centre, 313 Lincoln University, New Zealand.

\section{References}

315 Alaphilippe A, Capowiez Y, Severac G, Simon S, Saudreau M, Caruso S, and Vergnani S. 2016. 316 Codling moth exclusion netting: an overview of French and Italian experiences. $I O B C$ WPRS Bulletin 112.

318 Andorno AV, and López SN. 2014. Biological control of Myzus persicae (Hemiptera: Aphididae) through banker plant system in protected crops. Biological Control 78:9-14.

320 10.1016/j.biocontrol.2014.07.003

321

322

Auclair JL. 1963. Aphid feeding and nutrition. Annual Review of Entomology 8:439-490.

\section{3}

324

325

326

327

328

329

330 10.1146/annurev.en.08.010163.002255

Bass C, Puinean AM, Zimmer CT, Denholm I, Field LM, Foster SP, Gutbrod O, Nauen R, Slater R, and Williamson MS. 2014. The evolution of insecticide resistance in the peach potato aphid, Myzus persicae. Insect Biochemistry and Molecular Biology 51:41-51. 10.1016/j.ibmb.2014.05.003

Ben-Yakir D, Antignus Y, Offir Y, and Shahak Y. 2012a. Colored shading nets impede insect invasion and decrease the incidences of insect-transmitted viral diseases in vegetable crops. Entomologia Experimentalis et Applicata 144:249-257. 10.1111/j.15707458.2012.01293.x 
331 Ben-Yakir D, Antignus Y, Offir Y, and Shahak Y. 2012b. Optical manipulations of insect pests 332 for protecting agricultural crops. Acta Horticulturae 956:609-615. 10.17660/ActaHortic.2012.956.72

334 Ben-Yakir D, Antignus Y, Offir Y, and Shahak Y. 2014. Photoselective nets and screens can 335 reduce insect pests and diseases in agricultural crops. Acta Horticulturae 1015:95-102.

337 Bethke JA, Redak RA, and Paine TD. 1994. Screens deny specific pests entry to greenhouses. California Agriculture 48:37-40. 10.3733/ca.v048n03p37

339 Capinera JL. 2001. Green Peach Aphid, Myzus persicae (Sulzer) (Insecta: Hemiptera: Aphididae). Entomology and Nematology Department, Florida Cooperative Extension Service, Institute of Food and Agricultural Sciences, University of Florida. p 11.

342 Collier RH. 2001. Crop covers offer considerable opportunities for pest control. The Vegetable $343 \quad$ Farmer December 2001:18-20.

344 Collier RH. 2002. Using crop covers and mulches as an aid to pest control. The Vegetable $345 \quad$ Farmer December 2002:16-19.

346 Dáder B, Legarrea S, Moreno A, Plaza M, Carmo-Sousa M, Amor F, Viñuela E, and Fereres A. 347 2015. Control of insect vectors and plant viruses in protected crops by novel pyrethroidtreated nets. Pest Management Science 71:1397-1406. 10.1002/ps.3942

Dib H, Sauphanor B, and Capowiez Y. 2010. Effect of codling moth exclusion nets on the rosy 350 apple aphid, Dysaphis plantaginea, and its control by natural enemies. Crop Protection 29:1502-1513. 10.1016/j.cropro.2010.08.012 
352 Dixon AFG, and Wratten SD. 1971. Laboratory studies on aggregation, size and fecundity in the 353 black bean aphid, Aphis fabae Scop. Bulletin of Entomological Research 61:97-111. $10.1017 / \mathrm{S} 0007485300057485$

355

356

357

358

359

360

361

362

363

364

365

366

367

368

369

370

371

372

373

Ester A, Van de Zande JC, and Frost AJP. 1994. Crop covering to prevent pest damage to field vegetables, and the feasibility of pesticide application through polyethylene nets. Brighton crop protection conference: Pests and diseases -1994. Brighton, UK: The British Crop Protection Council. p 761-766.

FAOSTAT. 2020. Available at http://www.fao.org/faostat/en/\#compare (accessed 14 January 2020).

Foster SP, Devine G, and Devonshire AL. 2007. Insecticide resistance. In: Emden HF, and van Harrington R, eds. Aphids as crop pests. Oxford, UK: Oxford University Press, 261-286.

Frank SD. 2010. Biological control of arthropod pests using banker plant systems: Past progress and future directions. Biological Control 52:8-16. 10.1016/j.biocontrol.2009.09.011

Gagnon Lupien N, Aoun M, and Chouinard G. 2014. Le contrôle des pucerons par les coccinelles sous filets d'exclusion dans un verger de pommiers en régie biologique au Québec : L'efficacité de la coccinelle Adalia bipunctata comme moyen de lutte aux pucerons sous filet. Victoriaville, Québec, Canada: CETAB+ Le Centre d'expertise et de transfert en agriculture biologique et de proximité. p 5.

Geary IJ, Merfield CN, Hale RJ, Shaw MD, and Hodge S. 2016. Predation of nymphal tomato potato psyllid, Bactericera cockerelli (Šulc) (Hemiptera: Triozidae), by the predatory mite, Anystis baccarum L. (Trombidiformes: Anystidae). New Zealand Entomologist 39:110-116. 10.1080/00779962.2016.1218525 
374 Giordanengo P, Brunissen L, Rusterucci C, Vincent C, van Bel A, Dinant S, Girousse C, Faucher

375 M, and Bonnemain J-L. 2010. Compatible plant-aphid interactions: How aphids

376 manipulate plant responses. Comptes Rendus Biologies 333:516-523.

$377 \quad$ 10.1016/j.crvi.2010.03.007q

378 Gogo EO, Saidi M, Ochieng JM, Martin T, Baird V, and Ngouajio M. 2014. Microclimate

379 modification and insect pest exclusion using agronet improve pod yield and quality of

380 French bean. HortScience 49:1298-1304. 10.21273/HORTSCI.49.10.1298

381 Harcourt N. 1996. Evaluation of the potential of the Tasmanian brown lacewing, Micromus

382

tasmaniae Walker [Neuroptera: Hemerobiidae], as a biocontrol agent of aphids on

383 glasshouse capsicums M.Sc. Lincoln University.

384

Hill DS. 1987. Agricultural insect pests of temperate regions and their control. Cambridge, UK: Cambridge University Press.

Hodge S, Bluon A, and Merfield CN. 2019. Pore size requirements for mesh crop covers to protect potatoes from aphids. New Zealand Entomologist 41:66-71. $10.1080 / 00779962.2018 .1556914$

389

390

391 392

393

394

395

International Plant Protection Convention. 2017. Detection of Bactericera cockerelli (Tomatopotato psyllid) in Western Australia.

Jonsson M, Wratten SD, Robinson KA, and Sam SA. 2009. The impact of floral resources and omnivory on a four trophic level food web. Bulletin of Entomological Research 99:275285. $10.1017 / \mathrm{S} 0007485308006275$

Licciardi S, Assogba-Komlan F, Sidick I, Chandre F, Hougard JM, and Martin T. 2007. A temporary tunnel screen as an eco-friendly method for small-scale farmers to protect 
cabbage crops in Benin. International Journal of Tropical Insect Science 27:152-158.

397 $10.1017 / \mathrm{S} 1742758407883184$

398

399

400

401

402

403

404

405

406

407

408

409

410

411

412

413

414

415

416

417

Marczewski S. 2001. Potato leafroll virus-assisted aphid transmission of potato spindle tuber viroid to potato leafroll virus-resistant potato. Journal of Phytopathology 149:195-201. 10.1046/j.1439-0434.2001.00600.x

Martin T, Assogba-Komlan F, Houndete T, Hougard JM, and Chandre F. 2006. Efficacy of mosquito netting for sustainable small holders' cabbage production in Africa. Journal of Economic Entomology 99:450-454, 455. 10.1603/0022-0493-99.2.450

Martin T, Palix R, Kamal A, Delétré E, Bonafos R, Simon S, and Ngouajio M. 2013. A repellent net as a new technology to protect cabbage crops. Journal of Economic Entomology 106:1699-1706. 10.1603/EC13004

Merfield CN. 2017. Mesh crop covers for non-chemical potato pest \& disease control: Final results from the 2016-17 field trial of mesh vs. agrichemicals. Lincoln, New Zealand: The BHU Future Farming Centre. p 48.

Merfield CN. 2018. Testing the compatibility of mesh crop covers with desiccant sprays in seed potato production. Lincoln, New Zealand: The BHU Future Farming Centre. p 10.

Merfield CN, Geary IJ, Hale RJ, and Hodge S. 2015a. Field evaluation of the effectiveness of mesh crop covers for the protection of potatoes from tomato potato psyllid. New Zealand Journal of Crop and Horticultural Science 43:123-133. 10.1080/01140671.2015.1015576

Merfield CN, Hale RJ, and Hodge S. 2015b. Pore size criteria of mesh crop covers for the exclusion of tomato-potato psyllid (Bactericera cockerelli). New Zealand Journal of Crop and Horticultural Science 43:53-58. 10.1080/01140671.2014.949800 
418 Merfield CN, Winder L, Stilwell SA, Hofmann RW, Bennett JR, Wargent JJ, and Hodge S.

419

420

421

422

423

424

425

426

427

428

429

430

431

432

433

434

435

436

437

438

439

2019. Mesh crop covers improve potato yield and inhibit tomato potato psyllid and blight: The roles of mesh pore size and ultraviolet radiation. Annals of Applied Biology 174:223-237. 10.1111/aab.12489

Munyaneza JE. 2013. Bactericera cockerelli. EPPO Bulletin 43:202-208. 10.1111/epp.12044

Munyaneza JE. 2014. Bactericera cockerelli (tomato/potato psyllid). Available at https://www.cabi.org/isc/datasheet/45643 (accessed 14 January 2020).

O’Connell DM, Wratten SD, Pugh AR, and Barnes AM. 2012. 'New species association' biological control? Two coccinellid species and an invasive psyllid pest in New Zealand. Biological Control 62:86-92. 10.1016/j.biocontrol.2012.03.011

Pugh AR, O'Connell DM, and Wratten SD. 2015. Further evaluation of the southern ladybird (Cleobora mellyi) as a biological control agent of the invasive tomato-potato psyllid (Bactericera cockerelli). Biological Control 90:157-163.

\subsection{6/j.biocontrol.2015.06.009}

Radcliffe EB, and Ragsdale DW. 2002. Aphid-transmitted potato viruses: The importance of understanding vector biology. American Journal of Potato Research 79:353-386. 10.1007/BF02870173

Saguez J, Giordanengo P, Vincent C, and Alyokhin A. 2013. Aphids as major potato pests. In: Alyokhin A, Vincent C, and Giordanengo P, eds. Insect pests of potato. San Diego: Academic Press, 31-63.

Saidi M, Gogo EO, Itulya FM, Martin T, and Ngouajio M. 2013. Microclimate modification using eco-friendly nets and floating row covers improves tomato (Lycopersicon 
440

441

442 Srinivasan R, Cervantes FA, Alvarez JM, Alyokhin A, Vincent C, and Giordanengo P. 2013.

443

444

445

446

447

448

449

450

451

452

453

454

455

456

457

458

459

460

461 esculentum) yield and quality for small holder farmers in East Africa. Agricultural

Sciences 4:577-584. 10.4236/as.2013.411078 and Giordanengo P, eds. Insect pests of potato. San Diego: Academic Press, 311-337.

Stufkens M, and Teulon D. 2001. Aphids species on potato crops in Canterbury. New Zealand Plant Protection 54:235-239. 10.30843/nzpp.2001.54.3746

Talekar NS, Su FC, and Lin MY. 2003. How to grow safer leafy vegetables in nethouses and net tunnels. AVRDC pub \# 03-558. Shanhua; Taiwan: Asian Vegetable Research and Development Center. p 6.

Teulon DAJ, Workman PJ, Thomas KL, and Nielsen M-C. 2009. Bactericera cockerelli: incursion, dispersal and current distribution on vegetable crops in New Zealand. New Zealand Plant Protection 62:136-144.www.nzpps.org/nzpp_abstract.php?paper=621360

Vegetables.co.nz. 2020. Top vegetables by spend: Ranking of vegetables based on household expenditure. Available at https://www.vegetables.co.nz/education-and-resources/topvegetables-by-spend/ (accessed 14 January 2020).

Wallis RL. 1955. Ecological studies on the potato psyllid as a pest of potatoes. Washington: U.S. Dept. of Agriculture.

Woodford J. 1992. Virus transmission by aphids in potato crops. Netherlands Journal of Plant Pathology 98:47-54. 10.1007/BF01974471

Zamani AA, Talebi A, Fathipour Y, and Baniameri V. 2007. Effect of temperature on life history of Aphidius colemani and Aphidius matricariae (Hymenoptera: Braconidae), two 
parasitoids of Aphis gossypii and Myzus persicae (Homoptera: Aphididae).

463

Environmental Entomology 36:263-271. 10.1603/0046-225x-36.2.263

464

465

466 Figure and Table Legends

467

468

Fig. 1. Experimental set up: (1) top Petri dish, (2) bottom Petri dish, (3) hole for aphid

469 introduction, (4) mesh between dishes, (5) Eppendorf tube and leaflet. For the 8 'control'

470 treatments, aphids were placed below the mesh, while for the other 16 treatments, aphids were 471 placed above the mesh.

472

473 Table 1. Measurements of each mesh type.

474

475 Table 2. Mean $(\sqrt{ })$ number of aphid nymphs of apterous and alate parents breaching different 476 mesh sizes when leaflets were touching the mesh or not. A: Controls were statistically analysed. 477 B: Treatments with means in brackets indicate those that were omitted because they had zero 478 mean and zero variance. m.e. $=$ main effect.

479

480 


\section{Figure 1}

Fig. 1. Experimental set up: (1) top Petri dish, (2) bottom Petri dish, (3) hole for aphid introduction, (4) mesh between dishes, (5) Eppendorf tube and leaflet. For the 8 'control' treatments, aphids were placed below the mesh, while for the other 16 tre

\section{4}

\section{1}

\section{3}

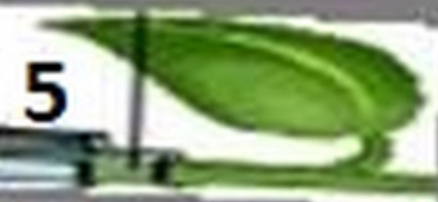




\section{Table $\mathbf{1}$ (on next page)}

Measurements of each mesh type. 
1

2 Table 1. Measurements of each mesh type.

\begin{tabular}{lllllllll}
\hline \multicolumn{7}{c}{ Mesh size $(\mathrm{mm})$} & \multicolumn{7}{l}{$0.3 \times 0.3$} & & $0.6 \times 0.6$ & \\
& $0.15 \times 0.15$ & $0.15 \times 0.35$ & $0.3 \times 0.3$ & & \\
\hline Mean & 0.14 & 0.13 & 0.15 & 0.32 & 0.37 & 0.23 & 0.52 & 0.52 \\
Max. & 0.16 & 0.15 & 0.18 & 0.37 & 0.53 & 0.31 & 0.57 & 0.55 \\
Min. & 0.12 & 0.10 & 0.12 & 0.30 & 0.27 & 0.17 & 0.45 & 0.47 \\
\hline
\end{tabular}

3 


\section{Table 2 (on next page)}

Mean $(\sqrt{ })$ number of aphid nymphs of apterous and alate parents breaching different mesh sizes when leaflets were touching the mesh or not. A: Controls were statistically analysed. B: Treatments with means in brackets indicate those that were omitted becaus 
1 Table 2. Mean $(\sqrt{ })$ number of aphid nymphs of apterous and alate parents breaching different 2 mesh sizes when leaflets were touching the mesh or not. A: Controls were statistically analysed. 3 B: Treatments with means in brackets indicate those that were omitted because they had zero 4 mean and zero variance. m.e. $=$ main effect.

$\begin{array}{llll}\text { Aphid } & \text { Mesh size } & \text { Mean of } & \text { Back } \\ \text { morph } & (\mathrm{mm}) & \begin{array}{l}\text { square root } \\ \text { of \# of } \\ \end{array} & \begin{array}{l}\text { nymphs } \\ \text { transformed } \\ \text { below mesh }\end{array} \\ & & \\ & & \end{array}$

\begin{tabular}{|c|c|c|c|c|}
\hline \multicolumn{5}{|l|}{ A. } \\
\hline \multirow[t]{8}{*}{ Control } & Apterous & $0.15 \times 0.15$ & 2.460 & 6.05 \\
\hline & & $0.15 \times 0.35$ & 2.202 & 4.85 \\
\hline & & $0.3 \times 0.3$ & 1.940 & 3.76 \\
\hline & & $0.6 \times 0.6$ & 2.448 & 5.99 \\
\hline & Alate & $0.15 \times 0.15$ & 1.823 & 3.32 \\
\hline & & $0.15 \times 0.35$ & 1.673 & 2.80 \\
\hline & & $0.3 \times 0.3$ & 2.455 & 6.03 \\
\hline & & $0.6 \times 0.6$ & 1.756 & 3.08 \\
\hline \multicolumn{3}{|l|}{ LSD 5\% } & 1.235 & \\
\hline \multicolumn{3}{|c|}{ Significance of m.e., apterous vs alate } & not sig. & \\
\hline \multicolumn{5}{|c|}{ B. } \\
\hline \multirow{8}{*}{$\begin{array}{l}\text { Leaflet not touching } \\
\text { mesh }\end{array}$} & Apterous & $0.15 \times 0.15$ & $(0.000)$ & 0.00 \\
\hline & & $0.15 \times 0.35$ & $(0.000)$ & 0.00 \\
\hline & & $0.3 \times 0.3$ & 0.483 & 0.23 \\
\hline & & $0.6 \times 0.6$ & 0.883 & 0.78 \\
\hline & Alate & $0.15 \times 0.15$ & $(0.000)$ & 0.00 \\
\hline & & $0.15 \times 0.35$ & 0.200 & 0.04 \\
\hline & & $0.3 \times 0.3$ & 0.283 & 0.08 \\
\hline & & $0.6 \times 0.6$ & 0.829 & 0.69 \\
\hline \multirow{8}{*}{$\begin{array}{l}\text { Leaflet touching } \\
\text { mesh }\end{array}$} & Apterous & $0.15 \times 0.15$ & $(0.000)$ & 0.00 \\
\hline & & $0.15 \times 0.35$ & $(0.000)$ & 0.00 \\
\hline & & $0.3 \times 0.3$ & 0.200 & 0.04 \\
\hline & & $0.6 \times 0.6$ & 0.400 & 0.16 \\
\hline & Alate & $0.15 \times 0.15$ & $(0.000)$ & 0.00 \\
\hline & & $0.15 \times 0.35$ & 0.546 & 0.30 \\
\hline & & $0.3 \times 0.3$ & 1.012 & 1.02 \\
\hline & & $0.6 \times 0.6$ & 1.029 & 1.06 \\
\hline LSD 5\% & & & 0.905 & \\
\hline
\end{tabular}

